\title{
An Ethnomedicinal Study of Important Medicinal Plants in Kudermukh National Park of Karnataka: A Review
}

\author{
Rahul Pradhan $^{1^{*}}$, T. N. Manohara ${ }^{1}$, H. S. Suresh ${ }^{2}$ and Amit Prakash Nayak ${ }^{3}$ \\ Department of Silviculture and Forest Management, Institute of Wood Science and \\ Technology (IWST-ICFRE), Bengaluru, Karnataka \\ ${ }^{2}$ Centre for Ecological Sciences, Indian Institute of Science (IISc), Bengaluru, Karnataka \\ Department of Forestry, Indira Gandhi Agricultural University, Raipur, Chhattisgarh, India \\ *Corresponding author
}

\section{A B S T R A C T}

\section{Keywords}

Ethnomedicinal, Native, Circulatory, Digestive

Article Info

Accepted:

26 August 2020

Available Online:

10 September 2020
This review article presents a list and uses of some medicinal plants distributed in the Kudermukh National Park of Karnataka. This paper provides information about 56ethno-medicinally useful plants grown in this region. In this paper, family, botanical name, local name, ethnomedicinal uses are given for each plant. All these plants are used in the treatment like injuries, respiratory ailments, circulatory system ailments, digestive disorders, colds, and fevers of human. This study represents a systematic attempt to explore the knowledge of the native people about plants, which they use to cure diseases and it is an attempt towards conserving the local knowledge of people to plants.

\section{Introduction}

It is documented that $80 \%$ of the world population has faith in traditional medicines, particularly plant drugs for their primary healthcare (Kala et al., 2006). The use of plants for medicinal purposes and human sustenance has been in practice in India since the Vedic age. The earliest mention of the medicinal use of the plants is found in the Rigveda, 1500-400 BC, Athurveda 1500 BC, Upnishada 1000-600 BC (Chauhan, 1999). In
India about 17000 species of higher plants out of which 7500 are known for medicinal uses (Shiva, 1996). India is one of the major contributors to the world in terms of herbal drugs and its raw materials (Grunwald, 2000). In India Janaki Ammal (1956) initiated the work on ethnobotany while working in botanical survey of India.

Kudremukh National Park is located at the trijunction of Dakshina Kannada, Udupi and Chikmagalur districts. It falls approximately 
at the middle of mid-Western Ghats (the stretch between Goa and Nilgiris). It lies to the south - west of Karnataka state and is just $50 \mathrm{kms}$. from the west-coast between the $75^{0}$ $01^{\prime}$ to $75^{\circ} 25^{\prime}$ east longitude and $13^{0} 01$ ' to $13^{0} 29^{\prime}$ north latitude. The National park is a part of Sahyadrihill ranges and constitutes a geographic barrier between the coastal areas and the hinterland. For ages this has segregated people and gave protection to the coastal areas, its wealth, its culture and traditions from casual invasion by the strong ruling polity of the maidan areas. The park derives its name from the highest hill peak known as the Kudremukh Peak having an altitude of 1892 meters from the sea level. It is the queen of many fascinating hill peaks in Karnataka.

\section{Materials and Methods}

Literature survey of publications related to traditional knowledge associated with plant resources of different tribes and communities in Western Ghats of India by various researchers were done. The literatures consist working plan of Kudermukh National Park, research papers in journals, contributed chapters in book and books available online, Pharmacognostical evaluation and in the Library of Institute of Wood Science and Technology, Bengaluru and Library of Department of Forestry, IGKV, Raipur. This review paper describes Ethnomedicinal (the medicinal usages of plants in the treatments of different ailments of human being) uses of important tree species are mentioned.

\section{Ethnomedicinal use of different tree species in Kudermukh National Park}

\section{Systematic descriptions}

\section{Lagerstroemia lanceolata Wall.}

Common name: Nandi tree FamilyLythraceae

\section{Ethnomedicinal uses}

Bark are used as stimulant, febrifuge and in stomachache. Leaf and flower are Purgative and hydragogue in nature. Root has astringent property and used as gargle.

\section{Sterculia foetida L.}

Common name- Wild almond tree, Java olive tree, Family-Malvaceae

\section{Ethnomedicinal uses}

The bark is aperient, diaphoretic and diuretic. It is used in the treatment of dropsy and rheumatism. The leaves are aperients. The fruit is astringent and mucilaginous. It is used in the treatment of gonorrhea. The seeds are used as a purgative in Ghana. The oil from the seed is laxative and carminative. It is extracted on a local scale to be used in medicine.

\section{Dalbergia latifolia Roxb.}

Common name - Rosewood, FamilyFabaceae

\section{Ethnomedicinal uses}

The bark is used in traditional medicine in India, to treat diarrhoea, indigestion and leprosy, and as a vermifuge.

\section{Spondias mangifera Willd.}

Common name- Indian hog plum, Wild mango, Family-Anacardiaceae

\section{Ethnomedicinal use}

The bark is rubifacient and is being used in Indian indigenous medicine over painful joints. Its paste is utilized as an embrocation for the both articular and muscular 
rheumatisms. It is refrigerant, aromatic and astringent too which is given to prevent vomiting and is used in the treatment of dysentery and diarrhea. is also used in the treatment of infectious diseases such as bronchitis, dysentery, ulcer, diarrhea and skin diseases.

\section{Calophyllum elatum Wall ex. Choisy}

Common name- Poonspar tree, sirpoon tree, Family-Clusiaceae

\section{Ethnomedicinal use}

Oil from calophyllum genus plants hasantiinflammatory and antibacterial properties.

Seed oil rubefacient, irritant, vermifuge used for ring worm ad rheumatism.

\section{Holigarna grahmii WightKurz}

Common name- Blistering varnish tree, Family- Anacardiaceae

\section{Ethnomedicinal use}

In Ayurveda, the plant is believed to be helpful in treatment of inflammation, arthritis, hemorrhoids, obesity, tumor, cancer, and skin diseases.

\section{Cedrela toona Roxb. ex Rottl. \&Willd.}

Common name- Mountain Cedar Indian cedar, Family- Meliaceae

\section{Ethnomedicinal use}

Various parts of the plant are used medicinally throughout its geographical range.

The bark is a powerful astringent, febrifuge, tonic, and antiperiodic. It is used to treat chronic dysentery and wounds. The flowers are emmenagogue.

Canarium strictum Roxb.

Common name- Black dammar FamilyBurseraeae

\section{Ethnomedicinal use}

Canarium strictum exudates a resin called as 'Sambrani' or 'Dammar' which has medicinal as well as commercial uses. It's mostly used among tribal and folk people for medicinal purposes and also used in Siddha system of medicine. The resin powder is given orally to cure rheumatism, fever, cough, asthma, epilepsy, chronic skin disorders, syphilis, and hernia and also helps to improve complexion

\section{Elaeocarpus tuberculatus Roxb.}

Common name -Warty marble tree, FamilyElaeocarpaceae

\section{Ethnomedicinal uses}

Rudraksha beads users have repeatedly confirmed the medicinal properties such as dielectrical energy and permanent magnetic properties, controls heart beat and has a positive effect on blood pressure, stress, anxiety, depression, palpitations and lack of concentration

Elaeocarpus bark have been known to possess antimicrobial anti-arthritic, anti-diabetic activities. Different parts of rudraksha were taken for the alleviation of various health related problems such as mental disorders, headache, skin diseases and for healing wounds. The bark is used for stomachic, antibilious problem.

\section{Bischofia javanica Blume}

Common name-Bishop wood, FamilyPhyllanthaceae 


\section{Ethnomedicinal use}

The plant has been shown has been shown to have antiulcer, anthelmintic and antidysenteric activities. The fresh bark is used to treat aching stomachs. The sap of the bark, mixed with lime, is used to treat sore feet. The crushed leaves are rubbed onto an aching stomach.

\section{Myristica malabarica Lam.}

Common name- Malabar nutmeg, FamliyMyristicaceae

\section{Ethnomedicinal uses}

The seeds are astringent. They are roasted, ground into powder and used in the treatment of diarrhea. The oil from the seed is used as an ointment to treat ulcers, ease rheumatism and allay pain. Both the aril and the seeds have been roasted, along with unripe plantains and a little opium, in order to cure dysentery.

\section{Litsea lam}

Common name-Listea, Family-Lauraceae

\section{Ethnomedicinal use}

It includes antibacterial, antifungal, acaricidal, insecticidal, antioxidant and anticancer properties. The plant possesses medicinal properties and has been traditionally used for curing various gastro-intestinal ailments (e.g., diarrhea, stomachache, indigestion, and gastroenteritis) along with diabetes, edema, cold, arthritis, asthma, and traumatic injury. Besides its medicinal properties, Litsea is known for its essential oil, which has protective action against several bacteria, possesses antioxidant and antiparasitic properties, exerts acute and genetic toxicity as well as cytotoxicity, and can even prevent several cancers.

\section{Cinnamomum malabathrum Burm.f.}

Common name: Wild Cinnamomum, FamilyLauraceae

\section{Ethnomedicinal uses}

It is used for treating wounds, fevers, intestinal worms, headaches and menstrual problems. The plant is also used for treatment of some tumours. The bark is used in the treatment of gastro-intestinal complaints such as dyspepsia, flatulence, diarrhoea and vomiting.

The leaves are carminative. They are used in the treatment of colic and rheumatism. They are sweetish and heating, making them useful in vata, scabies, disease of the anus and rectum, tridosha, piles and heart troubles. The dried buds are used with various combinations in the treatment of cough and urinary disease. The stem bark extract has been shown to possess a protective effect against tumours.

\section{Garcinia gummigutta L.N. Robson}

Common name- Malabar tamarind, FamilyClusiaceae

\section{Ethnomedicinal uses}

Root is used as traditional medicine for treating intestinal parasites, constipation, cancer, piles, bowels complaints, rheumatism, edema, delayed menstruation, demulcent, bilious affections and other diseases. Malabar tamarind is shown to possess antioxidant, antihelmintic, anticattarhal, anti-cancer and antimicrobial activities.

\section{Oroxylum indicum( L.) Kruz}

Common name- Indian trumpet flower, Sonapatha or Shyonaka, Family: Bignoniacea 


\section{Ethnomedicinal use}

Sonapatha possesses anticancer, antioxidant, hepatoprotective and immunomodulaory properties mainly. The bitter bark of the root is astringent, blood purifier and tonic. It is used in the treatment of stomach complaints, diarrhoea and dysentery. The root is credited with antirheumatic, antidysenteric and diuretic properties. The seeds and bark are used medicinally for alleviating body pain, especially during fevers and as an antiphlogistic medicine. It is also applied to burns and wounds. The juice of the bark is taken internally to treat diarrhoea and dysentery. A decoction of the bark is refrigerant, used in the treatment of fevers and jaundice. A decoction of the leaves is drunk as a treatment for stomach-ache and applied externally in the treatment of cholera, fever, childbirth and rheumatic swellings.

Symplocos racemosa Roxb.

Common name- Lodhra, Family: Symplocaceae

\section{Ethnomedicinal uses}

Bark has expectorant, astringent, febrifuge, anti-inflammatory, stomachic, haemostatic, suppurative and constipating properties. Leaves, bark and root is used for treating dysentery, diarrhea, uterine diseases, liver diseases, liver disorders, leprosy, uterine disorders, conjunctivitis and opthalmia. Bark powder is used to heal wounds. When combined with sugar, it is used to treat menorrhagia and other uterine disorders.

In Ayurveda, the herb is used to provide glow to skin and make body attractive. Decoction or cold infusion is provided in divided dose of 50-60 $\mathrm{ml}$ for treating uterine bleeding disorders. Apply the bark paste for rashes, itching and insect bites. The bark powder is sprinkled or blown inside the ear for controlling discharge from ears.

\section{Glochidin velutinum Wight}

Common name: Velvetymelon feather foil, Family: Euphorbiaceae.

\section{Ethnomedicinal use}

The whole plant as well as individual parts of the plant is used traditionally to cure a variety of human ailments like diabetes, inflammation, cancer, healing of wounds, anti-diarrheal activity etc. Various extracts of the plant have been reported to possess antidiabetic, antioxidant, antiurolithiatic, antibacterial activity etc.

\section{Memecylon edule Roxb.}

Common name-Kaayam, Family: Melastomataceae

\section{Ethnomedicinal uses}

The bark is used to treat bruises. An infusion of the flowers is used to treat inflammation of the conjunctiva.

\section{Macaranga peltate (Roxb.) Müll.Arg.}

Common name-Chandada, Family: Euphorbiaceae

\section{Ethnomedicinal use}

The leaves are used in a post-natal bath and as a repellent for ants. It is also used traditionally to treat convulsions, diarrhoea and as an abortifacient. Bark is used as a vermifuge, febrifuge, aperient and anti-anaemic tonic, and to treat cough, bronchitis and gonorrhoea. A decoction of the roots is applied against amenorrhoea, and as an emmenagogue and abortifacient, a decoction of the bark to treat 
cough, and a decoction of the leaves to treat gonorrhoea. The bark is also used as a purgative and against cough, and a decoction of the roots to treat oedema. The bark and roots are administered to treat asthma, cough, headache, rheumatism and for liver and stomach complaints, whereas a decoction of the bark is applied to toothache and thrush.

\section{Leea indica (Burm. f.) Merr.}

Common name: Bandicoot Berry Family: Vitaceae

\section{Ethnomedicinal uses}

The juice of young leaves is used as a digestive. Young shoots are chewed to relieve a severe cough. The pounded leaves are used for poulticing cuts and skin complaints in general. They are placed upon the head in cases of fever, headache and as a general anodyne for body pains. The leaf juice is applied on the head as a remedy for dizziness or vertigo. A decoction of the shoots is applied to sores. The root is considered antipyretic and diaphoretic. It is used to relieve muscular pain, and is an ingredient of a preparation to treat leucorrhoea, intestinal cancer and cancer of the uterus. A decoction of the roots is taken to relieve stomach-ache, colic, dysentery and diarrhoea.

The roots are an ingredient for a treatment against yaws. The crushed roots are applied as a poultice to treat ringworms, diarrhoea, colic and sores. The crushed root is also applied to rashes, stings, allergic reactions etc from other plants. An infusion of the inflorescence is used in the treatment of chest pain in children.

\section{Leea asiatica (L.) Ridsdale}

Common name: Banchalita, Family: Vitaceae

\section{Ethnomedicinal uses}

The juice of young leaves is used as a digestive juice. Young shoots are chewed to relieve a severe cough. The pounded leaves are used for poulticing cuts and skin complaints in general. They are placed upon the head in cases of fever, headache and as a general anodyne for body pains. The leaf juice is applied on the head as a remedy for dizziness or vertigo. A decoction of the shoots is applied to sores. In the Oro province the body is beaten for some time with leafy shoots to relieve body pains, fevers and sleeplessness. The root is considered antipyretic and diaphoretic. It is used to relieve muscular pain, and is an ingredient of a preparation to treat leucorrhoea, intestinal cancer and cancer of the uterus. A decoction of the roots is taken to relieve stomach-ache, colic, dysentery and diarrhoea. The roots are an ingredient for a treatment against yaws. The crushed roots are applied as a poultice to treat ringworms, diarrhoea, colic and sores. The crushed root is also applied to rashes, stings, allergic reactions etc from other plants. An infusion of the inflorescence is used in the treatment of chest pain in children.

\section{Callicarpa tomentosa (L.) Murr.}

Common name: French Mulberry, Family: Lamiaceae

\section{Ethnomedicinal uses}

The leaf juice is applied on the affected skin to cure scabies. The seeds are treated as to treat oral infections and "intestinal complaints", the leaf extract is used to treat rheumatism, the juice of the fruit is used to treat fever, and an aromatic oil from the roots is used to treat "disordered stomach". The root juice is used to "treat irregular menstruation" and to promote delayed menstruation, and the leaves are known to be chewed with salt as an anthelmintic. 


\section{Psychotria dalzelli Hook.f.}

Common name: Dalzell's Psychotria, Family: Rubiaceae

\section{Ethnomedicinal uses}

The juice that has been freshly pressed from the leaves are used as eyedrops for treating migraine headaches

Terminalia bellirica (Gaertn.) Roxb.

Common name- Myrobalan, Family: Combreteaceae

\section{Ethnomedicinal uses}

The fruit contains anthraquinones and tannins. It is anthelmintic, astringent (especially when ripe), digestive, tonic and laxative (especially when unripe). The fruit is used internally principally in the treatment of digestive and respiratory problems. In Indian herbal medicine the ripe fruit is used in cases of diarrhoea and indigestion, whilst the unripe fruit is used as a laxative in cases of chronic constipation. The fruit is often used to treat upper respiratory tract infections that cause symptoms of sore throats, hoarseness and coughs. Externally, the fruit is used to make a lotion for sore eyes.

\section{Pterocarpus marsumpium Roxb.}

Common name: Indian Kino TreeFamily: Fabaceae

\section{Ethnomedicinal uses}

Indian Kino is often used in herbal medicine in India, the leaves, bark and most commonly the resin being used. A strongly astringent herb, it is also alterative. In addition, various trials have shown a hypoglycaemic effect from an aqueous extract of the heartwood. The resin obtained from wounds in the bark is astringent. It is used in the treatment of chronic diarrhoea and the irritation caused by gastric infection and colitis. Although it has an unpleasant flavour, it makes a good mouthwash and gargle. It is commonly used in cases of toothache and also as a douche to treat vaginal discharge. The resin is applied topically in the treatment of skin conditions. The bark is used, either as a powder or in decoction, in the treatment of diarrhoea. A decoction of the bark is very useful for diabetic patients. The heartwood is considered to be anthelmintic, anti-inflammatory, antioxidant and astringent. It is used to treat a range of complaints. The bruised leaves are used as a poultice on boils, sores and skin diseases.

\section{Poeciloneuron indicum Bedd.}

Common name-Indian Milled-Leaf Tree, Family- Clusiaceae

\section{Ethnomedicinal use}

The heartwood is dark red; not clearly demarcated from the lighter-coloured sapwood. There are occasional very short, fine, white, concentrically running lines, especially in the sapwood. The wood is very hard and heavy. It is used to make ricepounders and, with its excellent qualities, endeavors have been made to introduce the timber as a sleeper and paving-block wood. The wood makes a good fuel

\section{Mesua ferrea (L.)}

Common name: Indian Rose Chestnut, Family: Callophyllaceae

\section{Ethnomedicinal uses}

A mixture of pounded kernels and seed oil is used for poulticing wounds. The seed-oil is used for treating itch, scabies and other skin eruptions, dandruff and 
rheumatism. The fruit is alterative and stimulant paste of the fruit is applied to boils The flowers are astringent and stomachic. A paste made from the flowers is used in the treatment of amoebic dysentery. A decoction of the flowers is drunk by women after childbirth.

Dipterocarpus indicus. Bedd.

Common name: New Guinea rosewood, Family: Dipterocarpaceae

\section{Ethnomedicinal uses}

Olea resin is applied for treating rheumatic complaints.

\section{Hopea parviflora Bedd.}

Common name: Iron wood of Malabar, Family: Dipterocarpaceae

\section{Ethnomedicinal uses}

The resin from the trunk is used to treat sores and wounds. The bark is astringent, used for treatment of diarrohea. It is also used to treat inflammation in gums.

Hopea ponga (Dennst.) Mabb.

Common name: Thingam, Family: Dipterocarpaceae

\section{Ethnomedicinal uses}

The plant parts showed a wide range of medicinal properties, such as antioxidant, antibacterial, anticancer, antifungal and antihepatotoxic.

\section{Palaquium ellipticum (Dalzell) Baill.}

Common name: Palai Family: Sapotaceae

\section{Ethnomedicinal uses}

Gutta-percha is a natural latex obtained from the sap of the tree. The latex is also used as a part of decoction with other medicinal plants to treat scars, wounds and skin infections.

\section{Aglaia barberi Gamble}

\section{Common name: Law's Aglaia, Family:} Meliaceae

\section{Ethnomedicinal uses}

The leaves are used in the treatment of headaches, it has insecticidal properties, antifungal, antiviral, antibacterial or anthelmintic bioactivity.

\section{Schleichera oleosa (Lour.) Oken}

Common name:Ceylon oak, Family: Sapindaceae

\section{Ethnomedicinal uses}

Powdered seeds are applied to wounds and ulcers of cattle to remove maggots. The bark is astringent and is used against leprotic ruptures, skin inflammations and ulcers, while an infusion is taken against malaria. The oil obtained from the seed is applied externally to cure itching, acne and other skin afflictions.

Massaging the oil into the scalp is said to promote the growth of hair lost through baldness. The pulp of the fruit is astringent and appetite inducing. An oil extracted from the seed, called 'kusum oil', is a valuable component of true Macassar oil used in hairdressing. It is also used for lighting purposes. The oil is also used in the batik industry, and in Southern India, as a cooling bath oil. 
Hopea wightiana Wall.

Common name: Ponga, Family: Dipterocarpaceae

\section{Ethnomedicinal uses}

The bark is astringent, used for treatment of diarrohea. It is also used to treat inflammation in gums. It is also used to treat incontinence.

Dysoxylum malabaricum Bedd. ex C. DC.

Common name: White cedar, Family: Meliaceae

\section{Ethnomedicinal uses}

The fruits and wood are used in traditional medicine. A decoction of the wood is useful in the treatment of arthritis, anorexia, cardiac debility, expelling intestinal worms, inflammation, leprosy \& rheumatism. The wood oil is used in treating ear and eye diseases.

\section{Dimocarpus longan Lour.}

Common name: Longan, Family: Sapindaceae,

\section{Ethnomedicinal uses}

The flesh of the fruit is administered as a stomachic, febrifuge and vermifuge, and is regarded as an antidote for poison. A decoction of the dried flesh is taken as a tonic and treatment for insomnia and neurasthenic neurosis. In both North and South Vietnam, the 'eye' of the longan seed is pressed against a snakebite in the belief that it will absorb the venom.

\section{Persea macrantha (Nees) Kosterm.}

Common name: Large-Flowered Bay Tree, Family: Lauraceae,

\section{Ethnomedicinal uses}

The mucilage of the Bark is used as a shampoo due to its cooling effect. The bark powder is used for mental upset, bark decoction is recommended for rheumatism and asthma. Leaf paste is applied for all types of Joint pains. Bark decoction is poured as Dhara for swellings and paste with mustard seeds is applied externally for bruises. Leaves are used externally to treat ulcers. Leaf and Bark mixture are used to treat fractures, weakness and debility.

\section{Lophopetalum wightianum Arn.}

Common name: Wight's Crest-Petal, Family: Celastraceae

\section{Ethnomedicinal uses}

Bark extract displayed marked antibacterial, antifungal and antioxidant activities.

\section{Garcinia indica (Thouars) Choisy}

Common name: Kokum, Family: Clusiaceae,

\section{Ethnomedicinal uses}

Garcinia indica, popularly known as Kokam, is a rich anti-oxidant and is well-known as a famous summer drink. The seed butter is used as a remedy in the treatment of dysentery and mucous diarrhoea. The aqueous extraction from the fruits of this species is also used in order to reduce anxiety. The root, bark, fruit and the seed oil are used to treat piles, abdominal disorders, mouth diseases and worm infestations. It is useful as an infusion, or by direct application, in skin ailments such as rashes caused by allergies. Kokum butter is an emollient helpful in the treatment of burns, scalds and chaffed skin. The fruits are steeped in sugar syrup to make amrutkokum which is drink to relieve sunstroke. 
Garcinia Morella (Gaertn.) Desr.

Common name: Indian gamboge tree, Family: Clusiaceae

\section{Ethnomedicinal uses}

Gamboge, a gum-resin obtained from the plant, is used as an ointment plant used by traditional healers for the treatment of inflammatory disorders. It is a strong purgative and hence used in ascites, worms, hypertension. Also useful in amenorrhea. It is a good complexion enhancer

\section{Garcinia xanthochymus Hook.f.}

Common name: Mysore gamboge, Family: Clusiaceae

\section{Ethnomedicinal uses}

The fruit as a whole or its extracts are used in treatment of various ailments like fever, stomach problems, skin diseases and sexual disorders. The plant is also used in treatment of various ailments of livestock.

\section{Diospyros ebenumJ.Koenig ex Retz.}

Common name: Malabar ebony, Family: Ebenaceae

\section{Ethnomedicinal uses}

A decoction of root-bark is used in rheumatism and swellings. The plant and parts, especially the fruit has been used as an anti-inflammatory and antipyretic drug in many local traditional medicines: Chinese herbal medicine, Tibetan medicine, and Ayurvedic medicine

\section{Holigarna arnottiana Wall. ex Hook. f.}

Common name: Malabar marking nut, Family: Anacardiaceae

\section{Ethnomedicinal uses}

The plant is believed to be helpful in treatment of inflammation, arthritis, hemorrhoids, obesity, tumor, cancer, and skin diseases by traditional medicine practitioners.

\section{Holigarna grahamii (Wight) Kurz}

Common name: Blistering Varnish Tree, Family Anacardiaceae

\section{Ethnomedicinal uses}

Leaves are dried and decoction is used to treat cough, cold, inflammation, tumor, cancer and various skin diseases.

\section{Eugenia singampattiana Beddome}

Common name: Jungle guava, Family: Myrtaceae

\section{Ethnomedicinal uses}

The plant is used to get relief from toothache, digestive problems, asthma, giddiness, body pain, rheumatism, gastric complaints and also as mouth freshener. A paste prepared from equal quantities of leaves and flowers are consumed to cure body pain and throat pain and tender fruits are consumed to relief from leg sores and rheumatism. A paste is being prepared from equal quantities of stems, leaves and flowers are consumed with palm sugar to get relief from gastric complaints

\section{Euonymus indicus Heyne ex Roxb.}

Common name: Indian Spindle Wood, Family: Celastraceae,

\section{Ethnomedicinal uses}

The bark is especially useful in the treatment of liver disorders which follow or accompany fevers. The seeds are strongly emetic and 
purgative. The fresh leaves, and the dried fruit and seeds, are used externally to treat scabies, lice (head, body or pubic), ticks and other skin parasites.

\section{Knema attenuate (Hook. f. \& Thomson) Warb.}

Common name: Raktamara (Kannda), Family: Myristicaceae

\section{Ethnomedicinal uses}

The bark of this tree has been used in folk medicines as an ingredient of Ashwagandha dinei $^{\text {ie }}$ (medicated ghee), used for the treatment of spleen disorders, breathing disorders and impaired taste sensation. It also possess antioxidant, liver protection, antiinflammatory and anti-cancer properties.

\section{Sterculia guttata Roxb.}

Common name: Spotted sterculia, Family: Malvaceae

\section{Ethnomedicinal uses}

Eating handful of seeds, they felt sleepy and could go without food for several hours. It is used to cure fever and diarrhoea with combination of other plant.

Chrysophyllum lanceolatum (Blume) A.DC., nom. illeg.

Common name:Nyatoh, Family: Sapotaceae

\section{Ethnomedicinal uses}

The leaves squeezed and used as a soothing ointment or moisturizer for treating dry skin, skin eruption and skin itches. Leaves are used for treating gastrointestinal diseases such as diarrhoea, stomachache and indigestion. Both the leaves, roots and barks used for preparing herbal medicines that can be applied on wounds, cuts, sprains and bruises for quick healing. The roots and seeds extracts can be used for seizing bleeding from fresh cuts, injuries and wounds thereby preventing microbial growth on the wound while facilitating the healing process of the injury.

Fruit is an excellent source of dietary fibre. As a result, consuming this fruit helps to increase satiety thus reducing food cravings and maintaining a balanced weight.

\section{Careya arborea Roxb.}

Common name: Kumbhi Tree, Family: Lecythidaceae

\section{Ethnomedicinal uses}

The fibrous bark has been applied medicinally for relieving body swellings. The juice of the bark, and the calices of the flowers, is astringent and mucilaginous. They are often used internally in India for treating coughs and colds, and are applied externally as an embrocation. An astringent gum exudes from the fruit and stem. The pulped leaves are used as a poultice. The bark of the tree and the sepals of the flowers are well-known Indian remedies, and are valued on account of their astringent and mucilaginous properties, being administered internally in coughs and colds and applied externally as an embrocation.

\section{Ixora nigricans R.Br. ex Wight \&Arn.}

Common name: Black ixora, Family: Rubiaceae

\section{Ethnomedicinal uses}

Extract of root is used to treat diarrhoea and ear infections by the Chakma. A paste of the leaves is applied to affected areas for the treatment of boils, pills prepared from the paste of the leaves are taken thrice daily for dysentery by the Tanchangya. Extract 
prepared from leaf taken and paste prepared from root is applied in the whole body as a remedy for unconsciousness of little child and extract prepared from root is applied in the whole body as a remedy for unconsciousness of little child and extract prepared from root, taken one cupful four times daily for two days against vomiting over bleeding.

\section{Hymenodictyon orixense (Roxb.) Mabb.}

Common name: Bridal Couch Plant, Family: Rubiaceae,

\section{Ethnomedicinal uses}

Bark used as astringent and febrifuge; leaves used to treat ulcers, sialitis, sore throat, tonsillitis. The bitter bark is used as astringent and febrifuge; root, wood and stem-bark used as for fevers. and to cure leucorrhea and menorrhea. The stem bark is used to treat enlarged spleen in babies. Whole plant decoction used in babies for diarrhoea and dysentery. Powdered wood used for herpes. Root juice mixed with the juice of bark of Callicarpa tomentosa used for fever. Leaves boiled in water used as bath in the treatment of jaundice.

\section{Pavetta indica $\mathbf{L}$.}

Common name: Indian Pellet Shrub, Family: Rubiaceae

\section{Ethnomedicinal uses}

Leaves are used for poulticing boils to remove pus. Leaves decoction used externally for piles. Crushed root bark, with rice water and ginger, taken as a diuretic and for dropsy; root, root bark or stem bark used for intestinal obstructions. Root diuretic, purgative, tonic, used in intestinal obstructions, intestinal disorders, dysentery, jaundice, headache, toothache, urinary diseases and dropsy; roots decoction as a postpartum remedy. Veterinary medicine, stem bark paste applied to maggotinfected sores.

\section{Terminalia paniculata Roth}

Common name: Flowering Murdah, Family: Combretaceae,

\section{Ethnomedicinal uses}

It reduces inflammation. Its external application helps in wound heating and early reunion of Fractures. It acts as a haemostatic.It is used in fever. It is used in diseases of pitta and kapha and also in disorders of rakta dhatu.

\section{Ventila gomadera spatana Gaertn}

Common name: Red creeper, Family: Rhamnaceae

\section{Ethnomedicinal uses}

The whole plant is used to treat many disorders like skin problems, fever, and diabetes and also used as digestive carminative. It is believed that it possesses the healing effect of dyspepsia, colic disorder, leprosy, scabies, pruritis and other skin disorders and general disability. The powder of stem bark mixed with gingelly oil is applied externally to treat skin diseases and itches. The root bark is used as a carminative, stomachic, stimulant and vitiated connection of kapha, colic flatulence and enysipelas. Latex of this plant is used to cure edema. Bark is also used to thermogenic, alexeteric, flatulence and tonic. Bark and leaves are used to cure malarial fever. Seeds mixed with milk or/and water has showed antidiabetic activity by taken directly.

\section{Zanthoxylum rhetsa (Roxb.) DC}

Common name: Indian ivy-rue, Family: Rutaceae, 


\section{Ethnomedicinal uses}

A decoction of the bark is taken internally as a cure for pains in the chest. The bark is pounded and mixed with oil then used externally as a remedy for stomach pains. When chewed it is applied to snakebites. The fruits are aromatic, astringent, stimulant, and stomachic. They are used in the treatment of dyspepsia, asthma and bronchitis, heart troubles, toothache and rheumatism. The skin of the fruit is credited with astringent, stimulant and digestive properties..

\section{Results and Discussion}

At the end of field study, we determined that the number of plants considered as medicinal plants in the research field is 56 species. These 56 species belong to 46 genera and 29 families. Among these 6 species belongs to Clusiaceae 4 species (4 genera) belong to Dipterocarpaceae and 3 species (3 genera) belong to Rubiaceae, Meliaceae, 3 species (4 Genera) belongs to Lauraceae, 2 species (2 genera each) from Fabaceae, Myristicaceae, Euphorbiaceae, Sapotaceae, Sapindaceae, Celastraceae and 2 species (1 genera each) belongs to Malvaceae, Vitaceae, and 3 species (2 genera) belongs to Anacardiaceae and 1 species belong the Lythraceae, Burseraceae, Elaeocarpaceae, Phyllanthaceae, Bignoniaceae, Symplocaceae, Melastomaceae, Lamiaceae, Combretacaeae, Callophylaceae, Ebneaceae, Myrtaceae, Lecythidaceae, Rhamnace and Rutacaea.

Hence concluded, in this study, 56 medicinal plants were identified and documented. Informants preferred to treat some ailments like intestinal disorders, dysentery, jaundice, gastrointestinal diseases, insomnia and neurasthenic neurosis. The traditional conservation practices such as sacred groves, sacred plants also echoed their closeness and love of nature.

\section{References}

Bawa KS, Setty S, Joseph G. 2007. Poverty, biodiversity and institutions in forestagriculture ecotones of the Western Ghats and Eastern Himalaya ranges of India. Agriculture, Ecosystems and Environment.121:287-295.

Chauhan, N.S. 1999. Medicinal and Aromatic Plants of Himachal Pradesh. Indus Publishing Company, New Delhi.

Fang X, Jr. Phoebe CH, Pezzuto JM, Fong $\mathrm{HH}$, Farnsworth NR, Yellin B and Hecht SM. 1984 Plant anticancer agents, XXXIV. Cucurbitacins from Elaeocarpus dolichostylus. J.Nat.Prod., 47 (6), 988 - 993.

Grunwald, H. 2000. An economic overview of herbal drug trade. WHO report, 1: $77-181$

Hussain SA. 2003. Kudremukh National Park, Karnataka: a profile and a strategy for the future. J Bombay Nat Hist Soc. 100(2\&3):202-213.

Kumar, S and Hamal, I.A. 2009. Wild Edibles of Kishtwar High Altitude National Park in Northwest Himalaya, Jammu and Kashmir (India). Ethnobotanical Leaflets, 13: 195-202. 2009.

Janaki Ammal, E.K. 1956. Introduction to the subsistence economy of India. In: L.T. William Jr. (Ed.) man's role in changing face of the earth. University of Chicago Press, Chicago: 324-335

Kala, C.P., Dhyani, P.P. and Sajwan, B.S. 2006. Developing the medicinal plant sector in North India: challenges and opportunities. J. Ethnobiology and Ethnomedicine.

Krishnamurthy SV, Reddy AHM, Gururaja KV. 2001. A new species of frog in the genus Nyctibatrachus (Anura: Ranidae) from Western Ghats, India. Curr Sci. 80(7): 887-891.

Shiva, M.P. 1996. Inventory of forest resources for sustainable management 
and biodiversity conservation. Indus Publishing Company, New Delhi.

Suruse, P. B., N.J. Duragkar, U.D. Shivhare, S.B. Bodele, 2010. Study of Antimicrobial Activity of Canarium strictum Gum Resin, Journal of
Pharmacognosy and Phytochemistry, 2(6), pp. 435-437.

Swamy HR, Proctor J. 1994. Rain forests and their soils in the Sringeri area of the Indian Western Ghats. Global Ecol Biodivers Lett. 4:140-150.

\section{How to cite this article:}

Rahul Pradhan, T. N. Manohara, H. S. Suresh and Amit Prakash Nayak. 2020. An Ethnomedicinal Study of Important Medicinal Plants in Kudermukh National Park of Karnataka: A Review. Int.J.Curr.Microbiol.App.Sci. 9(09): 3477-3490.

doi: https://doi.org/10.20546/ijcmas.2020.909.432 